\title{
THE EFFECT ON RESPIRATION OF THE OCCLUSION OF A BRONCHUS IN MAN DURING BRONCHOSPIROMETRY
}

\author{
By K. K. PUMP \\ (From the Division of Tuberculosis Control, Department of Health and Welfare, Willow Chest \\ Centre, Vancouver, B. C.)
}

(Submitted for publication March 17, 1953 ; accepted December 30, 1953)

During the course of a routine bronchospirometry on a patient suffering from pulmonary tuberculosis, the observation was made that when the catheter leading to one lung was clamped at the end of a normal expiration there was an immediate increase in tidal volume, in the functional residual capacity and in the respiratory rate in the other lung. This phenomenon persisted until the block was removed, whereupon these three factors returned to normal within three breaths.

Experiments in which a bronchus was occluded have been reported by many investigators (1-7). According to Andrus (2) ligation of a bronchus in dogs under ether anesthesia induced a 20 per cent increase in minute ventilation and the respiratory rate immediately after operation before the anesthetic had lost its effect. Twenty-four hours later the minute ventilation had increased by 32 per cent and the respiratory rate by 30 per cent (2). Churchill and Agassiz (3) found that occlusion of either the right pulmonary artery or of the right bronchus in animals caused almost identical increases in the minute ventilation. Clamping of the bronchus was attended by a high degree of respiratory difficulty and could not be maintained for any period of time. The authors felt that the surgery necessary to prepare the specimen may have profoundly disturbed the mechanical conditions of respiration. In four experiments on dogs, anesthetized with barbital sodium, Moore (8) observed that blocking the right bronchus at the end of expiration produced a relatively deep inspiration as the next movement of the lung and the respiratory rate immediately slowed. After five minutes the respiratory rate accelerated to 34 per minute, 13 per minute above the control level. When the right bronchus was blocked at the end of inspiration, the next movement of the lung was a relatively deep expiration and the respiratory rate immediately slowed but within three minutes accelerated to 38 per minute. Although no mention is made of a change in the functional residual capacity, the graph illustrating the respiratory movements before and after the block, shows a decrease when the right bronchus was blocked in inspiration. No such change can be seen when the block was applied at the end of expiration. In a study of the blood flow through a lung collapsed by occlusion of its bronchus, by the same author (9), the depth of breathing of the opposite lung was consistently found to be increased and the degree of increase was most marked after right-sided collapse. The effect on respiratory rate was variable. The minute ventilation was conspicuously increased in all of the experiments. From the data presented, it seems that the observations were made when the blocked lung was totally collapsed.

In man twó methods of blocking a lung have been used. The first consists of clamping the tube leading to one of the lumina of the double bronchoscope and the other of feeding pure nitrogen to one lung. The effect of blocking one lung in three normal subjects was studied with respect to the effect upon the other lung $(4,10)$. The blocking, by means of clamping the tube, was induced at the peak of a normal inspiration and in each instance a decrease in the functional residual capacity and an increase in the tidal volume occurred. The unblocked lung always hyperventilated but never to a high degree and the sudden cutting off of one lung from ventilation was tolerated with no great difficulty.

The study reported here was undertaken to investigate the frequency and the variability of the response which occurs following the blocking of one lung and the effect extensive pulmonary disease may have on this phenomenon.

\section{METHODS}

The subjects used for this study were eleven women and twenty-three men, all suffering from pulmonary tuberculosis and being evaluated for chest surgery. The age range was from 26 to 53 years and the duration of 
TABLE I

Respiration during occlusion of a bronchus * $\dagger$ A. Effect observed bilaterally

\begin{tabular}{|c|c|c|c|c|c|c|c|}
\hline Subject & & $\begin{array}{l}\text { M.V. before } \\
\text { block }\end{array}$ & $\begin{array}{l}\text { M.V. of the } \\
\text { 1st min. of } \\
\text { block }\end{array}$ & $\begin{array}{l}\text { Per cent } \\
\text { change }\end{array}$ & $\begin{array}{c}\text { F.R.C. } \\
\text { increase }\end{array}$ & $\begin{array}{l}\text { R.R. before } \\
\text { block } / \mathrm{min} \text {. }\end{array}$ & $\begin{array}{l}\text { R.R. during } \\
\text { 1st min. } \\
\text { of block }\end{array}$ \\
\hline 1. Mrs. H. & $\begin{array}{l}\text { R.L. } \\
\text { L.L. }\end{array}$ & $\begin{array}{c}c c . \\
3,760 \\
4,400\end{array}$ & $\begin{array}{c}c c . \\
4,710 \\
6,700\end{array}$ & $\begin{array}{l}+25 \\
+52\end{array}$ & $\begin{array}{c}c c . \\
106 \\
134\end{array}$ & $\begin{array}{l}17 \\
17\end{array}$ & $\begin{array}{l}20 \\
17\end{array}$ \\
\hline 2. Miss L. & $\begin{array}{l}\text { R.L. } \\
\text { L.L. }\end{array}$ & $\begin{array}{l}3,388 \\
2,674\end{array}$ & $\begin{array}{l}5,172 \\
3,903\end{array}$ & $\begin{array}{l}+55 \\
+46\end{array}$ & $\begin{array}{l}134 \\
187\end{array}$ & $\begin{array}{l}14 \\
14\end{array}$ & $\begin{array}{l}12 \\
11\end{array}$ \\
\hline \multirow[t]{2}{*}{ 3. Mr. R. } & $\begin{array}{l}\text { R.L. } \\
\text { L.L. }\end{array}$ & $\begin{array}{l}4,990 \\
5,790\end{array}$ & $\begin{array}{r}9,597 \\
10,125\end{array}$ & $\begin{array}{l}+92 \\
+75\end{array}$ & $\begin{array}{l}416 \\
562\end{array}$ & $\begin{array}{l}15 \\
15\end{array}$ & $\begin{array}{l}25 \\
30\end{array}$ \\
\hline & $\begin{array}{l}\text { R.L. } \\
\text { L.L. }\end{array}$ & $\begin{array}{l}4,078 \\
2,994\end{array}$ & $\begin{array}{l}5,530 \\
4,531\end{array}$ & $\begin{array}{l}+36 \\
+51\end{array}$ & $\begin{array}{l}160 \\
335\end{array}$ & $\begin{array}{l}14 \\
14\end{array}$ & $\begin{array}{l}20 \\
15\end{array}$ \\
\hline 4. Mr. W. & $\begin{array}{l}\text { R.L. } \\
\text { L.L. }\end{array}$ & $\begin{array}{l}4,740 \\
5,456\end{array}$ & $\begin{array}{l}8,260 \\
5,993\end{array}$ & $\begin{array}{l}+74 \\
+\quad 10\end{array}$ & $\begin{array}{l}160 \\
376\end{array}$ & $\begin{array}{l}14 \\
14\end{array}$ & $\begin{array}{l}18 \\
16\end{array}$ \\
\hline 5. Mr. F. & $\begin{array}{l}\text { R.L. } \\
\text { L.L. }\end{array}$ & $\begin{array}{l}3,420 \\
2,902\end{array}$ & $\begin{array}{l}4,850 \\
4,960\end{array}$ & $\begin{array}{l}+42 \\
+71\end{array}$ & $\begin{array}{r}80 \\
107\end{array}$ & $\begin{array}{l}13 \\
13\end{array}$ & $\begin{array}{l}15 \\
16\end{array}$ \\
\hline 6. Mr. H. & $\begin{array}{l}\text { R.L. } \\
\text { L.L. }\end{array}$ & $\begin{array}{l}4,840 \\
3,970\end{array}$ & $\begin{array}{l}6,120 \\
5,580\end{array}$ & $\begin{array}{l}+27 \\
+40\end{array}$ & $\begin{array}{r}214 \\
0\end{array}$ & $\begin{array}{l}16 \\
13\end{array}$ & $\begin{array}{l}15 \\
16\end{array}$ \\
\hline 7. Mr. Y. & $\begin{array}{l}\text { R.L. } \\
\text { L.L. }\end{array}$ & $\begin{array}{l}3,540 \\
5,375\end{array}$ & $\begin{array}{l}4,420 \\
8,360\end{array}$ & $\begin{array}{l}+25 \\
+56\end{array}$ & $\begin{array}{r}133 \\
0\end{array}$ & $\begin{array}{l}13 \\
13\end{array}$ & $\begin{array}{l}9 \\
8\end{array}$ \\
\hline 8. Mr. G. & $\begin{array}{l}\text { R.L. } \\
\text { L.L. }\end{array}$ & $\begin{array}{l}3,509 \\
4,542\end{array}$ & $\begin{array}{l}3,789 \\
6,472\end{array}$ & $\begin{array}{l}+8 \\
+42\end{array}$ & $\begin{array}{r}0 \\
134\end{array}$ & $\begin{array}{l}13 \\
13\end{array}$ & $\begin{array}{l}18 \\
15\end{array}$ \\
\hline 9. Mr. S. & $\begin{array}{l}\text { R.L. } \\
\text { L.L. }\end{array}$ & $\begin{array}{l}6,633 \\
1,478\end{array}$ & $\begin{array}{l}6,843 \\
3,114\end{array}$ & $\begin{array}{l}+\quad 3 \\
+111\end{array}$ & $\begin{array}{r}120 \\
0\end{array}$ & $\begin{array}{l}15 \\
15\end{array}$ & $\begin{array}{l}13 \\
22\end{array}$ \\
\hline 10. Mr. Hyd & $\begin{array}{l}\text { R.L. } \\
\text { L.L. }\end{array}$ & $\begin{array}{l}3,068 \\
4,784\end{array}$ & $\begin{array}{l}4,320 \\
5,411\end{array}$ & $\begin{array}{l}+409 \\
+\quad 13\end{array}$ & $\begin{array}{r}0 \\
375\end{array}$ & $\begin{array}{l}10 \\
10\end{array}$ & $\begin{array}{r}9 \\
10\end{array}$ \\
\hline 11. Mr. D. & $\begin{array}{l}\text { R.L. } \\
\text { L.L. }\end{array}$ & $\begin{array}{l}3,510 \\
5,340\end{array}$ & $\begin{array}{l}5,077 \\
5,751\end{array}$ & $\begin{array}{l}+44 \\
+\quad 8\end{array}$ & $\begin{array}{l}346 \\
322\end{array}$ & $\begin{array}{l}22 \\
24\end{array}$ & $\begin{array}{l}19 \\
23\end{array}$ \\
\hline 12. Mrs. B. & $\begin{array}{l}\text { R.L. } \\
\text { L.L. }\end{array}$ & $\begin{array}{l}2,710 \\
4,260\end{array}$ & $\begin{array}{l}3,840 \\
5,150\end{array}$ & $\begin{array}{l}+42 \\
+\quad 20\end{array}$ & $\begin{array}{l}27 \\
27\end{array}$ & $\begin{array}{l}20 \\
19\end{array}$ & $\begin{array}{l}29 \\
33\end{array}$ \\
\hline 13. Mr. L. & $\begin{array}{l}\text { R.L. } \\
\text { L.L. }\end{array}$ & $\begin{array}{l}3,456 \\
4,998\end{array}$ & $\begin{array}{l}4,290 \\
6,580\end{array}$ & $\begin{array}{l}+24 \\
+32\end{array}$ & $\begin{array}{l}213 \\
134\end{array}$ & $\begin{array}{l}20 \\
20\end{array}$ & $\begin{array}{l}20 \\
20\end{array}$ \\
\hline 14. Mr. W. & $\begin{array}{l}\text { R.L. } \\
\text { L.L. }\end{array}$ & $\begin{array}{l}3,760 \\
4,360\end{array}$ & $\begin{array}{l}5,290 \\
5,650\end{array}$ & $\begin{array}{l}+40 \\
+\quad 29\end{array}$ & $\begin{array}{l}80 \\
94\end{array}$ & $\begin{array}{l}15 \\
15\end{array}$ & $\begin{array}{l}20 \\
18\end{array}$ \\
\hline 15. Mr. A. & $\begin{array}{l}\text { R.L. } \\
\text { L.L. }\end{array}$ & $\begin{array}{l}3,625 \\
3,970\end{array}$ & $\begin{array}{l}5,040 \\
4,910\end{array}$ & $\begin{array}{l}+39 \\
+\quad 23\end{array}$ & $\begin{array}{l}319 \\
321\end{array}$ & $\begin{array}{l}12 \\
12\end{array}$ & $\begin{array}{l}17 \\
19\end{array}$ \\
\hline 16. Mrs. M. & $\begin{array}{l}\text { R.L. } \\
\text { L.L. }\end{array}$ & $\begin{array}{l}3,920 \\
1,875\end{array}$ & $\begin{array}{l}4,510 \\
3,240\end{array}$ & $\begin{array}{l}+15 \\
+67\end{array}$ & $\begin{array}{l}266 \\
242\end{array}$ & $\begin{array}{l}14 \\
14\end{array}$ & $\begin{array}{l}14 \\
21\end{array}$ \\
\hline 17. Mr. C. & $\begin{array}{l}\text { R.L. } \\
\text { L.L. }\end{array}$ & $\begin{array}{l}3,460 \\
3,440\end{array}$ & $\begin{array}{l}6,750 \\
4,590\end{array}$ & $\begin{array}{l}+95 \\
+33\end{array}$ & $\begin{array}{l}453 \\
268\end{array}$ & $\begin{array}{l}15 \\
15\end{array}$ & $\begin{array}{l}15 \\
15\end{array}$ \\
\hline 18. Miss Mc. & $\begin{array}{l}\text { R.L. } \\
\text { L.L. }\end{array}$ & $\begin{array}{l}2,790 \\
4,000\end{array}$ & $\begin{array}{l}3,860 \\
5,065\end{array}$ & $\begin{array}{l}+38 \\
+33\end{array}$ & $\begin{array}{r}80 \\
161\end{array}$ & $\begin{array}{l}16 \\
16\end{array}$ & $\begin{array}{l}19 \\
17\end{array}$ \\
\hline 19. Mr. Sp. & $\begin{array}{l}\text { R.L. } \\
\text { L.L. }\end{array}$ & $\begin{array}{l}2,800 \\
6,320\end{array}$ & $\begin{array}{l}4,260 \\
8,420\end{array}$ & $\begin{array}{l}+52 \\
+\quad 33\end{array}$ & $\begin{array}{l}133 \\
107\end{array}$ & $\begin{array}{l}12 \\
12\end{array}$ & $\begin{array}{l}18 \\
17\end{array}$ \\
\hline 20. Miss J. & $\begin{array}{l}\text { R.L. } \\
\text { L.L. }\end{array}$ & $\begin{array}{l}2,910 \\
2,570\end{array}$ & $\begin{array}{l}3,570 \\
3,860\end{array}$ & $\begin{array}{l}+22 \\
+50\end{array}$ & $\begin{array}{l}160 \\
121\end{array}$ & $\begin{array}{l}12 \\
12\end{array}$ & $\begin{array}{l}11 \\
13\end{array}$ \\
\hline 21. Mr. Hry & $\begin{array}{l}\text { R.L. } \\
\text { L.L. }\end{array}$ & $\begin{array}{l}3,620 \\
3,610\end{array}$ & $\begin{array}{l}4,180 \\
4,350\end{array}$ & $\begin{array}{l}+\quad 15 \\
+\quad 20\end{array}$ & $\begin{array}{l}266 \\
188\end{array}$ & $\begin{array}{l}8 \\
8\end{array}$ & $\begin{array}{l}8 \\
8\end{array}$ \\
\hline 22. Mr. K. P. & $\begin{array}{l}\text { R.L. } \\
\text { L.L. }\end{array}$ & $\begin{array}{l}3,381 \\
3,316\end{array}$ & $\begin{array}{l}9,358 \\
7,518\end{array}$ & $\begin{array}{l}+177 \\
+127\end{array}$ & $\begin{array}{l}451 \\
376\end{array}$ & $\begin{array}{l}16 \\
16\end{array}$ & $\begin{array}{l}22 \\
26\end{array}$ \\
\hline
\end{tabular}

* M.V.-Minute Ventilation.

F.R.C.-Functional Residual Capacity.

R.R.--Respiratory Rate.

R.L.-Right Lung.

L.L.-Left Lung.

In each instance data recorded for a lung is in response to the blocking of the contralateral lung. 
TABLE I-Continued

B. Effect observed on one side only

\begin{tabular}{|c|c|c|c|c|c|c|c|}
\hline Subject & & $\begin{array}{l}\text { M.V. before } \\
\text { block }\end{array}$ & $\begin{array}{l}\text { M.V. of the } \\
\text { 1st min. of } \\
\text { block }\end{array}$ & $\begin{array}{l}\text { Per cent } \\
\text { change }\end{array}$ & $\begin{array}{c}\text { F.R.C. } \\
\text { increase }\end{array}$ & $\begin{array}{l}\text { R.R. before } \\
\text { block } / \mathrm{min} \text {. }\end{array}$ & $\begin{array}{l}\text { R.R. during } \\
\text { 1st min. } \\
\text { of block } \\
\end{array}$ \\
\hline 23. Mrs. R. L. & $\begin{array}{l}\text { R.L. } \\
\text { L.L. }\end{array}$ & $\begin{array}{c}c c . \\
6,790 \\
860\end{array}$ & $\begin{array}{c}c c . \\
6,150 \\
1,500\end{array}$ & $\begin{array}{l}-9 \\
+74\end{array}$ & $\begin{array}{r}c c . \\
0 \\
65\end{array}$ & $\begin{array}{l}15 \\
15\end{array}$ & $\begin{array}{l}12 \\
17\end{array}$ \\
\hline \multirow[t]{2}{*}{ 24. Mr. C. S. } & $\begin{array}{l}\text { R.L. } \\
\text { L.L. }\end{array}$ & $\begin{array}{l}4,800 \\
2,645\end{array}$ & $\begin{array}{l}5,166 \\
4,794\end{array}$ & $\begin{array}{l}+7 \\
+81\end{array}$ & $\begin{array}{r}0 \\
161\end{array}$ & $\begin{array}{l}15 \\
15\end{array}$ & $\begin{array}{l}16 \\
16\end{array}$ \\
\hline & $\begin{array}{l}\text { R.L. } \\
\text { L.L. }\end{array}$ & $\begin{array}{l}5,498 \\
2,080\end{array}$ & $\begin{array}{l}5,705 \\
2,499\end{array}$ & $\begin{array}{l}+4 \\
+20\end{array}$ & $\begin{array}{r}0 \\
54\end{array}$ & $\begin{array}{l}13 \\
13\end{array}$ & $\begin{array}{l}13 \\
14\end{array}$ \\
\hline 25. Miss W. & $\begin{array}{l}\text { R.L. } \\
\text { L.L. }\end{array}$ & $\begin{array}{r}6,230 \\
562\end{array}$ & $\begin{array}{l}6,566 \\
2,280\end{array}$ & $\begin{array}{l}+5 \\
+405\end{array}$ & $\begin{array}{l}\mathbf{0} \\
0\end{array}$ & $\begin{array}{l}22 \\
22\end{array}$ & $\begin{array}{l}22 \\
30\end{array}$ \\
\hline 26. Mr.S. M. & $\begin{array}{l}\text { R.L. } \\
\text { L.L. }\end{array}$ & $\begin{array}{l}3,890 \\
5,025\end{array}$ & $\begin{array}{r}5,061 \\
10,878\end{array}$ & $\begin{array}{l}+30 \\
+116\end{array}$ & $\begin{array}{r}0 \\
134\end{array}$ & $\begin{array}{l}23 \\
20\end{array}$ & $\begin{array}{l}23 \\
24\end{array}$ \\
\hline 27. M. A. & $\begin{array}{l}\text { R.L. } \\
\text { L.L. }\end{array}$ & $\begin{array}{l}3,450 \\
4,360\end{array}$ & $\begin{array}{l}3,680 \\
4,700\end{array}$ & $\begin{array}{l}+\quad 7 \\
+\quad 7\end{array}$ & $\begin{array}{r}40 \\
0\end{array}$ & $\begin{array}{l}23 \\
22\end{array}$ & $\begin{array}{l}20 \\
22\end{array}$ \\
\hline
\end{tabular}

C. Effect absent (one side not subjected to blocking)

\begin{tabular}{|c|c|c|c|c|c|c|c|}
\hline 28. Mr. St. & $\begin{array}{l}\text { R.L. } \\
\text { L.L. }\end{array}$ & $\begin{array}{r}265 \\
4,210\end{array}$ & $\overline{5,260}$ & +24 & $\cdot-\overline{0}$ & $\overline{22}$ & $\overline{24}$ \\
\hline 29. Mr. Sdn. & $\begin{array}{l}\text { R.L. } \\
\text { L.L. }\end{array}$ & $\begin{array}{r}6,630 \\
800\end{array}$ & $\stackrel{7,140}{-}$ & +7 & 0 & 17 & 16 \\
\hline 30. Mr. Apy. & $\begin{array}{l}\text { R.L. } \\
\text { L.L. }\end{array}$ & $\begin{array}{r}5,423 \\
990\end{array}$ & $\stackrel{5,150}{-}$ & -5 & $\underline{0}$ & 13 & 13 \\
\hline 31. Mr. K. & $\begin{array}{l}\text { R.L. } \\
\text { L.L. }\end{array}$ & $\begin{array}{r}5,190 \\
135\end{array}$ & $\begin{array}{c}5,090 \\
-\end{array}$ & $-{ }^{2}$ & $\underline{0}$ & 17 & 24 \\
\hline
\end{tabular}

D. Unilateral effect (other side not subjected to blocking)

\begin{tabular}{|c|c|c|c|c|c|c|c|}
\hline 32. Mrs.A.A. & $\begin{array}{l}\text { R.L. } \\
\text { L.L. }\end{array}$ & $\begin{array}{r}960 \\
4,990\end{array}$ & $\overline{5,500}$ & -10 & $\overline{228}$ & $\overline{20}$ & $\overline{20}$ \\
\hline 33. Mr. Wgr. & $\begin{array}{l}\text { R.L. } \\
\text { L.L. }\end{array}$ & $\begin{array}{l}4,540 \\
3,650\end{array}$ & $\begin{array}{c}5,024 \\
-\end{array}$ & $-^{11}$ & $\frac{347}{-}$ & 20 & 20 \\
\hline \multicolumn{8}{|c|}{ E. Unilateral effect, other side doubtful } \\
\hline 34. Mr. Hg. & $\begin{array}{l}\text { R.L. } \\
\text { L.L. }\end{array}$ & $\begin{array}{l}2,610 \\
2,690\end{array}$ & $\begin{array}{l}3,990 \\
3,640\end{array}$ & $\begin{array}{r}+52 \\
+35\end{array}$ & $\begin{array}{r}146 \\
0\end{array}$ & $\begin{array}{l}14 \\
14\end{array}$ & $\begin{array}{l}13 \\
14\end{array}$ \\
\hline \multicolumn{8}{|c|}{ F. No effect bilaterally } \\
\hline \multirow[t]{2}{*}{ 35. Mrs. O. } & $\begin{array}{l}\text { R.L. } \\
\text { L.L. }\end{array}$ & $\begin{array}{l}3,860 \\
3,680\end{array}$ & $\begin{array}{l}3,520 \\
3,700\end{array}$ & $\begin{array}{r}9 \\
-\quad 0\end{array}$ & $\begin{array}{l}0 \\
0\end{array}$ & $\begin{array}{l}10 \\
10\end{array}$ & $\begin{array}{l}11 \\
11\end{array}$ \\
\hline & $\begin{array}{l}\text { R.L. } \\
\text { L.L. }\end{array}$ & $\begin{array}{l}2,653 \\
3,488\end{array}$ & $\begin{array}{l}2,595 \\
4,418\end{array}$ & $\begin{array}{r}3 \\
+\quad 26\end{array}$ & $\begin{array}{l}0 \\
0\end{array}$ & $\begin{array}{l}10 \\
10\end{array}$ & $\begin{array}{l}11 \\
11\end{array}$ \\
\hline
\end{tabular}

pulmonary tuberculosis was from one to fifteen years. The patients were fasting (six hours) and received as premedication pentobarbital $100 \mathrm{mg}$., morphine sulphate $7.5 \mathrm{mg}$., and atropine $0.7 \mathrm{mg}$. during the two and one-half hours preceding bronchospirometry. Intermittent postural drainage was carried out for one hour immediately preceding bronchospirometry. The pharynx and tracheobronchial tree were anesthetized with 1 per cent pontocaine and Surfacaine (Lilly) jelly was applied to the exterior of the catheter. In addition to the 34 patients, one normal male was investigated (K. P. Table I). He did not receive pre-medication except for atropine.

Bronchospirometry was carried out with the patient in the supine position.

A Zavod catheter was inserted into the trachea by direct vision and guided under fluoroscopy into the left bronchus 3.5 to $4 \mathrm{~cm}$. below the carina. The exact position was checked by means of $\mathrm{x}$-ray. In the occasional pa- 
tient it was not possible to guide the catheter into the left bronchus because of strictures or marked deviation of the trachea.

While bronchospirometry was being carried out the effect of blocking a lung on the rhythm of respiration was studied. A McKesson bronchospirometer was used which records inspiration on the graph as an upstroke and expiration as a downstroke. Changes in the relative oxygen saturation were followed with an AP-4 Paul oximeter.

The patient was allowed to breathe oxygen with both lungs for six to eight minutes, after which vital capacities were taken. The two methods of Jacobœus and Bruce $(4,10)$ for blocking a lung were used. The first consisted of clamping, by means of forceps, the catheter leading to the lung to be blocked and the second, feeding pure nitrogen to the lung to be blocked and pure oxygen to the other. An additional feature was the clamping, by means of forceps, of the catheter leading to the lung breathing nitrogen, in order to rule out the possibility that the reactions occurring immediately after clamping the catheter were due to hypoxia. The clamping was done at the end of a normal expiration and in seven patients additional blocking was done at the height of inspiration.

Early in our investigation the patients could see when the forceps were applied to the catheter but the act was not explained to them. The interposition of a screen, so that the patient could not observe the clamping, did not change the reaction of the patients to the blocking procedures. They did not know when nitrogen was administered.

In the graphs presented, the upper graph is from the right lung and the lower graph from the left lung. The figures immediately above or below the graphs indicate the minute ventilation in cc. before and during the first minute of the block. The relative oximeter readings, present in some figures, are expressed in percentage of the initial reading at the start of the experiment and are placed along the top of the figure.

The vertical lines represent time with ten small squares equal to sixty seconds. The horizontal lines indicate the volumes with each small square equal to $53 \mathrm{cc}$.

The catheter was clamped at the end of a normal expiration and the arrow indicates the time at which the catheter was clamped or released. Because of technical arrangements the writing pen recording the inspirations of the right lung is one and one-half small squares to the right of the pen recording movements of the left lung. In Figures 2 through 6 the patients were breathing pure oxygen with both lungs. The response obtained when the lungs breathing nitrogen were blocked is not shown, except in Figure 1, but it is essentially the same as that obtained when the same lungs breathing pure oxygen were blocked.

The accompanying tables show the analyses of the three characteristic features of this phenomenon in the patients investigated. In these tables the values recorded for the heading "R.L." indicate the response obtained from the right lung prior and during the blocking of the left lung and vice versa.

The minute ventilation and the respiratory rate during the blocking of a lung are always calculated for the first minute only after the application of the block, whereas the increase in the functional residual capacity is representative for the whole period of the block.

\section{RESULTS}

In the first observation with this method ( $\mathrm{Pt}$. No. 1, Table I), the tidal volume and the functional residual capacity were immediately increased when the right lung was blocked (Figure 1-A). The sudden change in the manner of breathing was disturbing and it was only because the patient did not appear in distress and the oximeter showed no marked change in the oxygen saturation that the block was not immediately discontinued. When subsequently the left lung was blocked (Figure 1-B) it was strange to find that the same reaction was not obtained.

Blocking the left lung produced an immediate increase in the respiratory rate and only a gradual increase in the tidal volume and the functional residual capacity. It was considered unlikely that hypoxia played a part since the phenomenon occurred regardless of whether the lung which was blocked was breathing oxygen or nitrogen ( $\mathrm{C}$ and D) and also because the response occurred immediately on blocking the lung and before the oximeter readings indicated any sign of oxygen unsaturation. The lack of increase in tidal volume occurred on the side where thoracoplasty had been performed five years before, suggesting that the failure was due to some abnormality in the tissues of this lung. However, when our next patient (Pt. No. 2, Table I) showed a well-defined response on the diseased side as well as on the normal side, our explanation was no longer tenable.

It was soon apparent that the blocking procedure did not produce the same pattern of reaction in all patients and although the phenomenon was well defined in the majority, it was less evident in others. The three prominent features of blocking a lung were an increase in the functional residual capacity, an increase in the tidal volume and increase in the respiratory rate. Some patients exhibited all three, whereas in others one or two features were not present. Each case was, therefore, analyzed to determine whether the phenomenon was bilateral or unilateral and how many of the three components of the reaction were present. 


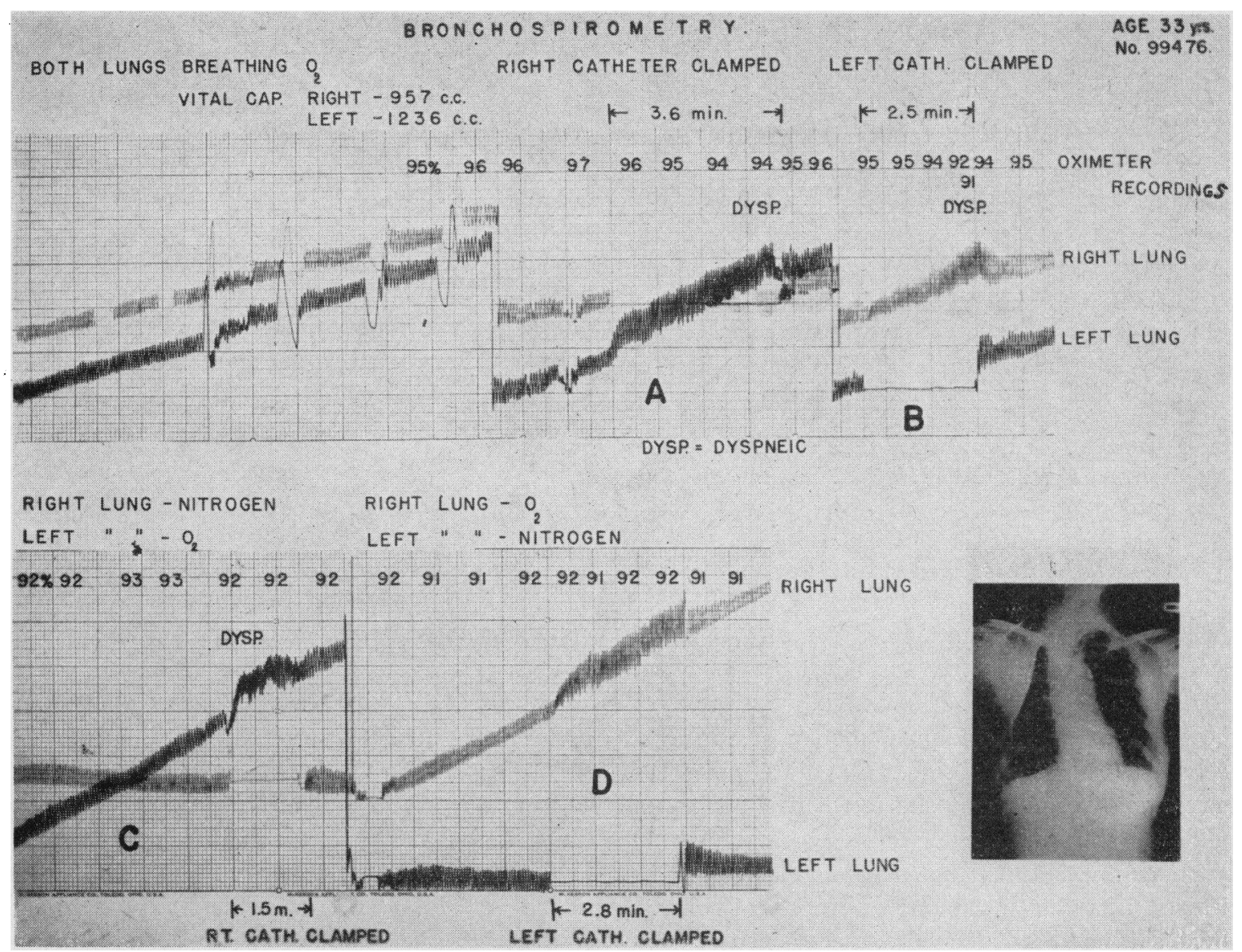

Fig. 1. (Patient No. 1, Table I) Illustration of the Method Used for Studying the Effect on Respiration When Blocking a Lung While Breathing Oxygen (A and B) and While Breathing Pure NitroGEN (C AND D)

Figure 2 (Pt. No. 3, Table I) shows the dramatic immediate response of the right lung when the left lung was blocked and again of the left lung when the right lung was blocked. As soon as the catheter was clamped the patient started to breathe deeply, almost gasping, but he did not appear alarmed or anxious. When questioned later he volunteered the information that he suddenly felt a tightness in his chest and a sensation that he could not get enough air. The tightness was not localized to one or the other side but was over the whole chest. Furthermore, the patient could not distinguish whether the right or the left lung had been blocked. With the onset of the sensation of tightness, he became apprehensive and dyspnoeic. With the release of the block this sensation subsided as suddenly as it had started. Another subject stated that when a lung was blocked at the end of a normal expiration, inspiration im- mediately became very difficult. After the block had been present for approximately a minute, inspiration became easier and the feeling of tightness diminished.

Patient No. 3 was again investigated three months after a right upper lobectomy had been performed. He again exhibited the phenomenon on both sides but it was not as marked. The patient stated that by now he was familiar with the procedure and did not become as apprehensive. Nevertheless, the response was still very marked as can be seen from the table. Although the increase in the functional residual capacity in this patient was the highest in our series, the phenomenon as shown in Figure 2 is representative of the reactions seen in the twenty-one patients in whom a bilateral response was obtained. On releasing the block, the return to the previous volume and respiratory rate was very rapid. 


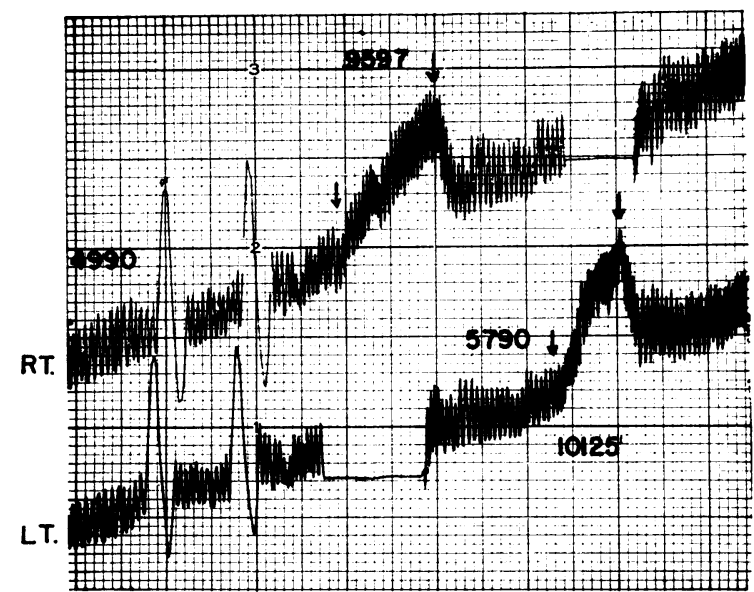

Fig. 2. (Patient No. 3, Tabie I) Patient with Bilateral, Localized, Apical Disease Shows Marked Effect on Respiration When Either Luxgis Biocked

Chest $\mathrm{x}$-ray of patient No. 3 revealed bilateral cavitation, otherwise the parenchyma was clear.

In contrast, Figure 3 (Pt. No. 35, Table I) shows an absence of the phenomenon on the right as well as on the left side. On questioning the patient she related that she too had a feeling of sudden tightness in the chest accompanied by dyspnoea and she felt that she was gasping. She differed, however, in the one respect that she knew which side had been blocked. There is no apparent reason from the $\mathrm{x}$-ray why the response to blocking should have differed to this extent.

Figure 4 (Pt. No. 26, Table I) shows a unilateral response. Blocking the right lung increased the minute ventilation, the functional resicl- ual capacity and the respiratory rate of the left lung, but blocking the left lung elicited no response except for an increase in the minute ventilation of the right lung. Blocking the right lung induced marked cyanosis. X-ray revealed pulmonary fibrosis with basal emphysema, more marked on the left side.

Our series inclucled six patients in whom the respiratory function of one lung was severely reduced, with a minute ventilation of less than one liter. In four of these patients (Pts. No. 28, 29, 30 , and 31, Table I) only the poor lung was blocked and no appreciable response was elicited (similar to the response seen in Figure 5-A). However, in the other two patients (Pts. No. 23 and 25, Table I) we blocked both the right and the left lung alternately. Blocking the poor lung (Figure 5-A) yielded no response, but blocking the good lung (Figure 5-B) elicited a marked response in both patients.

The most striking feature of this phenomenon occurring immediately after the blocking of a lung is the increase in the functional residual capacity and in cases where this increase was very marked there was usually an accompanying increase in tidal volume and respiratory rate. In one patient (Pt. No. 7. I. L., Table I) the functional residual capacity did not increase and an actual slowing of the respiratory rate occurred but the increase in the tidal volume was so great and the increase began so abruptly after the clamping of the catheter, that the total response was considered to be the same phenomenon but expressed

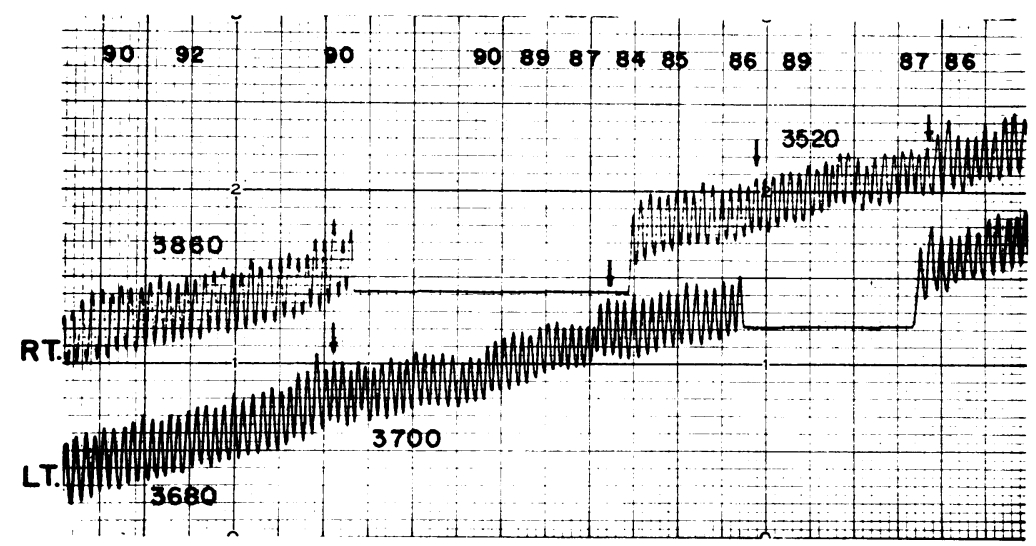

Fig. 3. (Patient No. 34, Table IV) Blocking Either the Right or the Left Lung Shows No Significant Alteration in the Minute Ventilation, the Functional Residual Capacity and the Respiratory Rate 


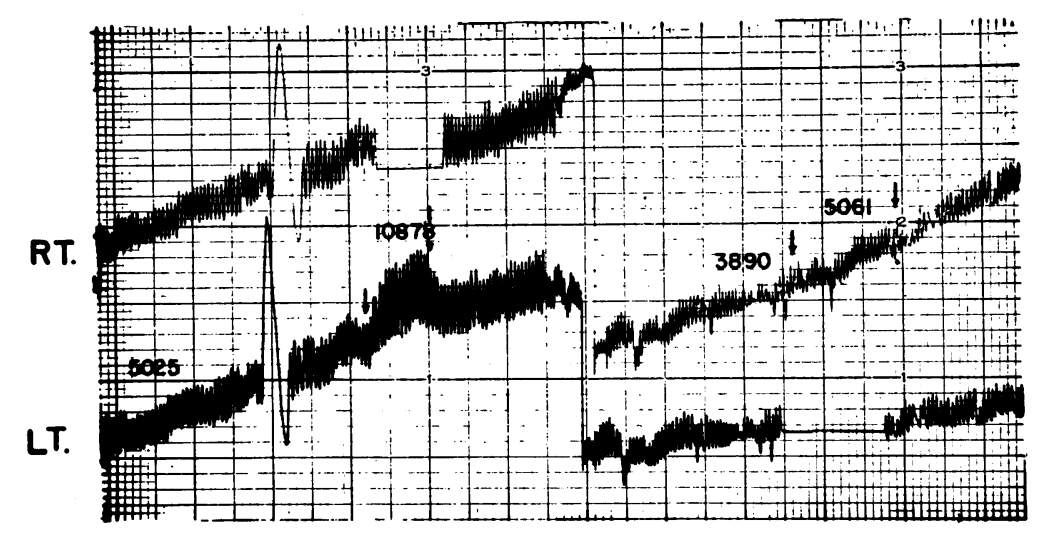

Fig. 4. (Patient No. 25, Table II) Functional Residual Capacity and Respiratory Rate Are Altered Only When the Right Lung is BLOCKED

in a different form. Another patient (Pt. No. 12, Table I) exhibited only a slight increase in the functional residual capacity and the tidal volume was diminished but there was a marked increase in the respiratory rate and again the change occurred immediately after the application of the block (Figure 6-A). Patients exhibiting this type of response, as a rule showed an encased lung limited in its movement due to extensive pleural disease.

An increase of the respiratory rate and of the tidal volume which occurred only after the block had been applied for some time was not considered characteristic of the phenomenon under discussion.

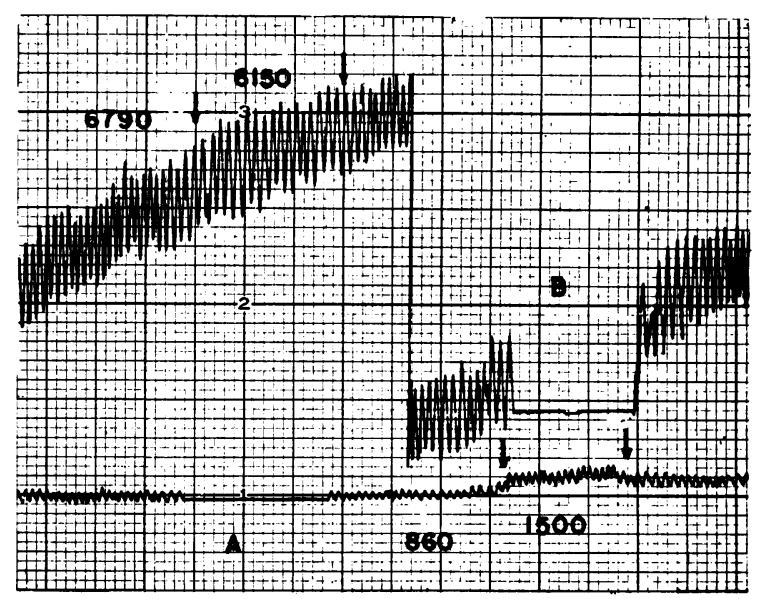

Fig. 5. Blocking a Lung with Severely Reduced Respiratory Function Has No Effect on the Other Lung, but Blocking the Good Lung Elicits a Marked Response in the Poor Lung
Of the 34 patients investigated 21 (61 per cent) exhibited the response bilaterally (Table I). In seven patients the response was present only on one side but in two of these only the side which exhibited the phenomenon was tested. (Table I, Pts. No. 32 and 33). In four patients only one lung was tested and no response was elicited (Table I, Pts. No. 28 to 31). The lung, which was blocked had very poor function with a minute ventilation of less than one liter. Only one patient (Pt. No. 35 , Table I) showed a complete bilateral absence of this phenomenon. This failure of response occurred on two different occasions (Figure 3). If each lung is considered individually, 49 positive reactions were obtained in the 34 patients and in 42 of the reactions the functional residual capacity was increased by $27 \mathrm{cc}$. to $562 \mathrm{cc}$. All responses indicated an increase in minute ventilation ranging from 3 per cent to 405 per cent above the value prior to blocking. The respiratory rate was increased in 27 out of the 49 positive reactions. The most marked increase in respiratory rate was from 19 per min. before blocking to 33 per min. immediately after blocking (Table I, Pt. No. 12, L. L.).

During the above investigations a lung was always blocked at the end of a normal expiration. Seven patients were studied to determine whether the response differed if a lung was blocked at the peak of a forced inspiration. Figure 6 shows the response obtained in one of the patients ( $\mathrm{Pt}$. No. 12, Table I). The left lung was blocked (A) at the end of a normal expiration and the right lung 
responded immediately with a greatly increased respiratory rate, minute ventilation and a small increase in the functional residual capacity. The right lung was then blocked (B) at the peak of an inspiration and the response of the left lung differed considerably. The respiratory rate accelerated only toward the end of the block, which accounts for the increase in the minute ventilation. In this instance the functional residual capacity was slightly decreased, returning to the normal level as the block was released. The right lung was again blocked in full inspiration (C) and the pattern was repeated, showing again a small decrease in functional residual capacity. The respiratory rate by now was a little more accelerated. particularly toward the end of the block. Finally. the right lung was blocked at the end of a normal expiration (D). There was an immediate increase in the respiratory rate and a small increase in the functional residual capacity, similar to the increase when the left lung was blocked at the end of a normal expiration.

The x-ray of this patient showed marked bilateral pleural thickening and an elevated right diaphragm.

It is reasonable to assume that just as the pattern of response after blocking a lung at the end of a normal expiration can vary, so can the pattern when the block is imposed at the height of an inspiration. Nevertheless, each type of block has its basic pattern. Too few patients have been examined to characterize this basic pattern, but it would appear that a decrease of the functional residual capacity is a prominent feature and practically all show a slowing of the respiratory rate during the first minute immediately following the block in inspiration. The minute volume, as a rule, increases too as the tidal volume may show a marked increase.

The sensations experienced when the lung is blocked at the peak of a forced inspiration differ from the feelings experienced when the lung is blocked at the end of a normal expiration. There is not the feeling of tightness nor of dyspnoea even though there is an increase in minute ventilation. There is a marked desire to empty the lung and in doing so, there is no sense of obstruction.

\section{DISCUSSION}

The mechanism for the respiratory changes induced by blocking a single lung are not understood. Hypoxia induced by the blocking of a lung appears not to be responsible for the changed pattern of respiration because hypoxia is not induced immediately on blocking a lung, as indicated by the oximeter, whereas the change in the breathing pattern is immediate. Secondly, if hypoxia did play a part, changes in the breathing pattern would occur while the lung was breathing pure nitrogen and before the block was applied to this lung. The possibility that retention of carbon dioxide may be responsible has not been excluded.

Jacobœus and Bruce $(4,10)$ noticed a decrease in the functional residual capacity when they

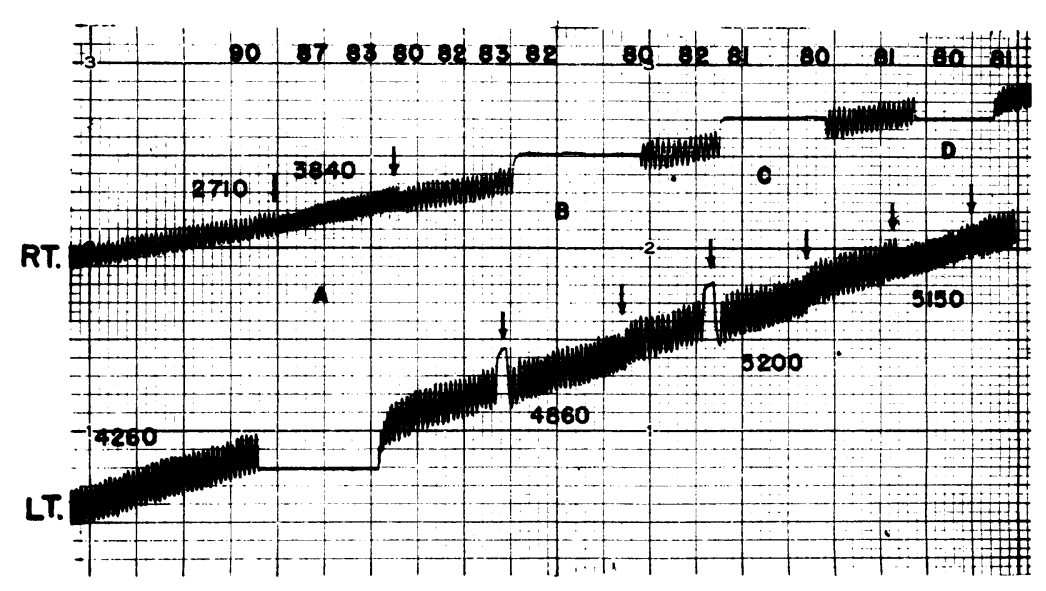

Fig. 6. (Patient No. 12, Table I) Comparing the Effects Produced When Blocking a Lung at the End of a Normal Expiration and Then at the Peak of a Forced Inspiration 
blocked a lung in inspiration and suggested that this response was due to a change in the mechanics of respiration causing the tidal air to encroach upon the reserve air. The mechanism may be as follows: if one lung is blocked at the end of a normal expiration, the remaining lung will with the subsequent inspiration, have a tidal volume equal to that of the two lungs providing the mediastinum will shift to such an extent. On expiration, however, the former functional residual capacity would be resumed. If the block is imposed in full inspiration, the remaining lung may with the subsequent expiration, expire a volume greater than its inspiratory reserve volume, again dependent on a freely moving mediastinum, and maintain this smaller functional residual volume as the fully distended blocked lung may displace the mediastinum toward the opposite side.

This mechanism may account for the increase in tidal volume and in the case where the block is imposed in full inspiration, for the decrease in the functional residual capacity, but does not explain the change in respiratory rate and the increase in the functional residual capacity when the block is imposed at the end of a normal expiration.

We favor the hypothesis that this phenomenon is due to the Hering-Breuer reflex $(11,12)$. This reflex would be dependent on the integrity of the stretch receptors in the lung parenchyma. It is possible that blocking a lung at the end of a normal expiration creates a situation in which the stretch receptors are less stimulated and consequently the inspiratory center is proportionately less inhibited. This would cause a more active inspiration bringing about an increase in tidal volume and the expiratory effort is decreased resulting in an increase in the functional residual capacity. It is conceivable that the respiratory rate would increase because the more powerful action of the inspiratory center overcomes the inhibiting effect of the expiratory center, and thus decreases the pause which ordinarily follows normal expiration (13-16). Blocking the lung in inspiration would have the reverse effect.

Whatever the cause, the phenomenon which occurs following the blocking of a lung appears to vary in different patients. Although this variation in many patients appears to depend on the extent and severity of lung disease, this is not always the case. In the majority of instances where an absence of a response was observed, it occurred when a severely handicapped or almost destroyed lung was blocked (Pts. No. 28, 29, 30 and 31). Patients who exhibited marked acceleration of the respiratory rate during the blocking of a lung, commonly presented evidence of ventilatory insufficiency due to such factors as pleural thickening, elevated and restricted or paralyzed diaphragm and thoracoplasty in the unblocked lung.

\section{SUM MARY}

1. Blocking one lung at the end of a normal expiration may bring about an immediate increase in the tidal volume, in the functional residual capacity and in the respiratory rate in the contralateral lung.

2. Blocking a markedly diseased lung, with a minute ventilation of less than one liter, fails to elicit such a response.

3. A lung with ventilatory insufficiency due to such factors as pleural thickening, elevated and restricted or paralyzed diaphragm and thoracoplasty, responds with a marked acceleration of the respiratory rate and with minor changes in tidal volume and functional residual capacity when the contralateral lung is blocked at the end of a normal expiration.

4. Blocking one lung at the peak of a forced inspiration causes a decrease in the functional residual capacity and a slowing or maintenance of the respiratory rate. The tidal volume usually increases.

\section{ACKNOWLEDGMENT}

The author wishes to express his gratitude to Drs. G. Wright, D. Mowat, and W. J. McLaren for their helpful suggestions. The keen interest taken in this work by Dr. R. B. Kerr and the technical assistance rendered by Mrs. R. Wallace, are especially appreciated.

\section{REFERENCES}

1. Adams, D. K., and Morris, N., Anoxaemia and the administration of oxygen. Proceedings of the Physiological Society, Jan. 22, 1921, J. Physiol., 1921, 54, C II.

2. Andrus, W. D., Observations on the cardiorespiratory physiology following the collapse of one lung by bronchial ligation. Arch. Surg., 1925, 10, 506.

3. Churchill, E. D., and Agassiz, A., A method for separating the air breathed by the right and the left lungs, together with the effect of pulmonary 
circulatory changes on this divided breathing. Am. J. Physiol., 1926, 7.6, 6.

4. Jacobœus, H. C., and Bruce, T., A bronchospirometric study on the ability of the human lung to substitute for one another. I. Acta med. Scandinav., 1940, 105, 193.

5. Loewy, A., and Schrötter, H. von, Untersuchungen über die Blutcirculation beim Menschen. Ztschr. f. exper. Path. u. Therap., 1905, 1, 197.

6. Kurusu, M., Matsushige, T., and Iba, T., Uber den Einfluss des einseitigen Bronchialverschlusses auf Lungengaswechsel, Blutgas und besonders Blutstrommenge beider Lungenhälften. Mitt. a. d. med. Akad. zu Kioto, 1938, 23, 1089.

7. Moore, R. L., and Cochran, H. W., The effects of closed pneumothorax, partial occlusion of one primary bronchus, phrenicectomy and the respiration of nitrogen by one lung on pulmonary expansion and the minute volume of blood flowing through the lungs. J. Thoracic Surg., 1933, 2, 468.

8. Moore, R. L., A study of the Hering-Breuer reflex. J. Exper. Med., 1927, 46, 819.
9. Moore, R. L., The volume of blood flow per minute through the lungs following collapse of one lung by occlusion of its bronchus. Experimental observations. Arch. Surg., 1931, 22, 225.

10. Jacobøus, H. C., and Bruce, T., A bronchospirometric study on the ability of the human lung to substitute for one another. II. Acta med. Scandinav., 1940, 105, 211.

11. Breuer, J., Die Selbststeuerung der Athmung durch den Nervus Vagus. Sitz. ber. Akad. Wiss., Wien, Abt. 2, 1868, 58, 909.

12. Hering, E., Die Selbststeuerung der Athmung durch den Nervus Vagus. Sitz ber Akad. Wiss., Wien, Abt. 2, 1868, 57, 672 .

13. Adrian, E. D., Afferent impulses in the vagus and their effect on respiration. J. Physiol., 1933, 79, 332.

14. Pitts; R. F., The function of components of the respiratory complex. J. Neurophysiol., 1942, 5, 403.

15. Pitts, R. F., The differentiation of respiratory centers. Am. J. Physiol., 1941, 134, 192.

16. Stella, G., On the mechanism of production, and the physiological significance of "Apneusis." J. Physiol., 1938, 93, 10. 